\title{
RESEARCH OF THE ASSORTMENT AND MERCHANDISING ANALYSIS OF ANTI-EPILEPTIC DRUGS PRESENTED AT THE PHARMACEUTICAL MARKET OF UKRAINE
}

\author{
T.V.Trunova \\ National University of Pharmacy \\ Key words: epilepsy; anti-epileptic drugs; dosage form; suppositories
}

\begin{abstract}
According to the contemporary statistics, epilepsy is one of the most serious and widespread diseases of the nervous system. According to the WHO data epilepsy affects about 50 million people worldwide, in particular in Ukraine there are 500000 patients with epilepsy, among them about $65 \%$ are children and adolescents. Adequate treatment of this pathology is one of the most difficult in clinical neurology and psychiatry. The research of the Ukrainian pharmaceutical market of anti-epileptic drugs has been conducted by the form of production and manufacturing countries; the need for these remedies at the social level has been determined. Consumer properties of drugs in the form of suppositories and their prospects in development of epilepsy treatment that will solve the problem of creating new, more effective and less toxic drugs for the treatment of this pathology have been analyzed. The greater part of drugs of this group is imported to Ukraine by foreign pharmaceutical companies. These circumstances lead to the fact that each year there are a lot of diverse studies for searching new potential anti-epileptic drugs. purposefulness of search generalizes all studies in this area both in case of creating analogues of the existing medicines, and in case of their possible metabolic products. In view of the above it can be concluded that the solution of the problem of creating new, more effective and less toxic drugs for the treatment of epilepsy is relevant and promising for medical and pharmaceutical science. Increase of the treatment efficiency and safety can only be done with the help of modern drugs.
\end{abstract}

According to the contemporary statistics, epilepsy is one of the most serious and widespread diseases of the nervous system. According to the WHO data epilepsy affects about 50 million people worldwide, in particular in Ukraine there are 500000 patients with epilepsy, among them about $65 \%$ are children and adolescents [6]. Adequate treatment of this pathology is one of the most difficult in clinical neurology and psychiatry [9]. The treatment of epilepsy is long, in many cases life-long. Most anti-epileptic drugs are intended for oral use [4], but in certain categories of patients (disease of stomach, dysphagia, etc.), this route of administration is not acceptable. Therefore, creation of drugs with the given action in more appropriate dosage forms is topical.

\section{Experimental Part}

Research of the anti-epileptic drugs range represented at the pharmaceutical market of Ukraine, identification of the leading manufacturing countries, the ratio of medicines of foreign and domestic production, analysis of consumer properties of drugs in the form of suppositories and the prospects of their development in treating epilepsy have been conducted.

According to the ATC International Classification these drugs belong to the anatomical group of $\mathrm{N}$ - drugs acting on the nervous system, the pharmacological group of N03 - anti-epileptic drugs [2, 7].

According to the State Register of Medicinal Remedies in Ukraine as of September, 2013, 164 drugs for the treatment of epilepsy have been registered [1]. Most of the drug range $-77 \%$ are foreign-made medi- cines and $23 \%$ of anti-epileptic drugs are produced in Ukraine.

Among domestic manufacturers of the group of drugs under research most of them are from "Kyiv Vitamin Plant" PJSC, "Lugansk Chemical and Pharmaceutical Plant" JSC, "Pharmaceutical company "Darnitsya" JSC, "ASTRAFARM" JSC, "Pharmaceutical company "Zdorovya" JSC, "Start Pharma" JSC, "Farmak" JSC. The main importing countries are Germany, India, Austria, Poland, France, Bulgaria, Israel, etc. (Fig. 1).

After having analyzed the data from the State Register of Medicinal Remedies it has been found that the anti-epileptic drugs are maily tablets $-80 \%$, capsules about $14 \%$, syrups and solutions - almost $2 \%$, suspensions and powders $-1 \%$ (Fig. 2).

\section{Results and Discussion}

Despite the fact that the range of anticonvulsants in the world every year gains even greater expansion, the problem of creating new medicines continues to be very relevant in Ukraine. At the Ukrainian pharmaceutical market there is monotony and the lack of the range of drugs with the anxiolytic effect.

In Europe, for the treatment of epilepsy valproates and carbamazepine are primarily used. In Ukraine of newly synthesized drugs lamotrigine, topiramate, felbamate, habapentin are registered and widely used, but they are not used in Europe and the USA because of the excessive toxicity $[5,8,10]$.

The the greater part of drugs of this group is imported to Ukraine by foreign pharmaceutical companies. 


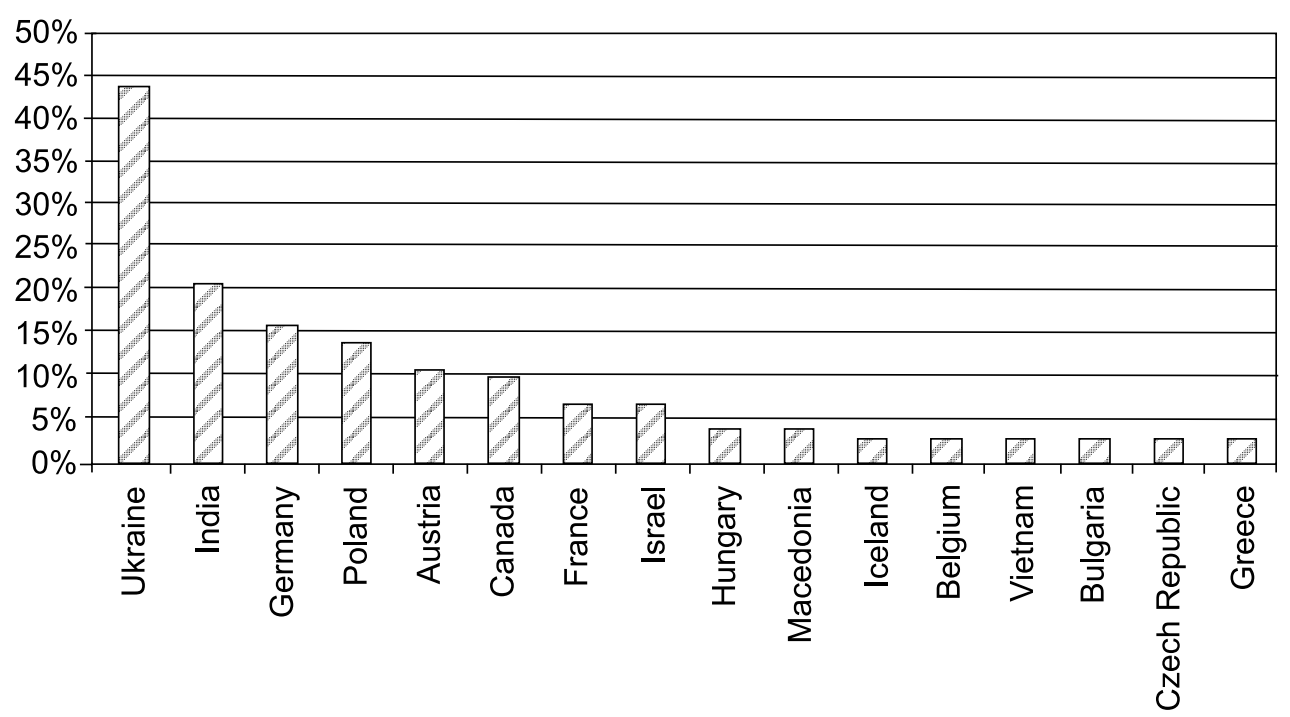

Fig. 1. The range of anti-epileptic drugs, in percentage, at the pharmaceutical market of Ukraine depending on the manufacturing country as of September 2013.

These circumstances lead to the fact that each year there are a lot of diverse studies for searching new potential anti-epileptic drugs. purposefulness of search generalizes all studies in this area both in case of creating analogues of the existing medicines, and in case of their possible metabolic products [14].

Anti-epileptic drugs in the form of suppositories at the Ukrainian market, as well as in most world pharmaceutical markets are not represented at all, but there are developments in this direction [13].

Thus, for the treatment of epileptic diseases suppositories are industrially produced in Finland, and in many European countries suppositories for the treatment of convulsive diseases are produced under conditions of pharmacies by individual formulas [9, 10]. For rectal application nowadays only diazepam and chloral hydrate are used. The dose of diazepam in suppositories is $0.2-0.5 \mathrm{mg} / \mathrm{kg}$. Peak concentrations in the blood serum is achieved in 20-60 $\mathrm{min}$.

In Ukraine development and implementation in industrial production of a new domestic drug in the form of suppositories will greatly expand the domestic market of drugs for the treatment of epileptic disorders.
Suppositories gain in popularity around the world, the rate of their production growth is ahead of similar indicators of other dosage forms. The range of suppositories both of the local and systemic action in developed countries covers almost all pharmacological groups and has more than a thousand of names [3].

For patients with epilepsy taking a medicine on time is very important. For example, drugs in the form of suppositories do not require taking the medicine at night. It gives consumers an advantage to maintain the concentration of the drug in the blood during the day and undoubtedly reduces the frequency of drug administration.

For consumers of the elderly age and children the route of administration is of interest, especially in the treatment of epilepsy, which requires long-term administration and the rapid action of drugs. Patients with epilepsy require long-term, often life-long treatment, but the low standard of living does not allow them to fully apply all the drug potential existing in the world today. Pharmacological effects of suppositories is much faster than those of the oral dosage forms. This is an advantage of the dosage form to consumers as it is related

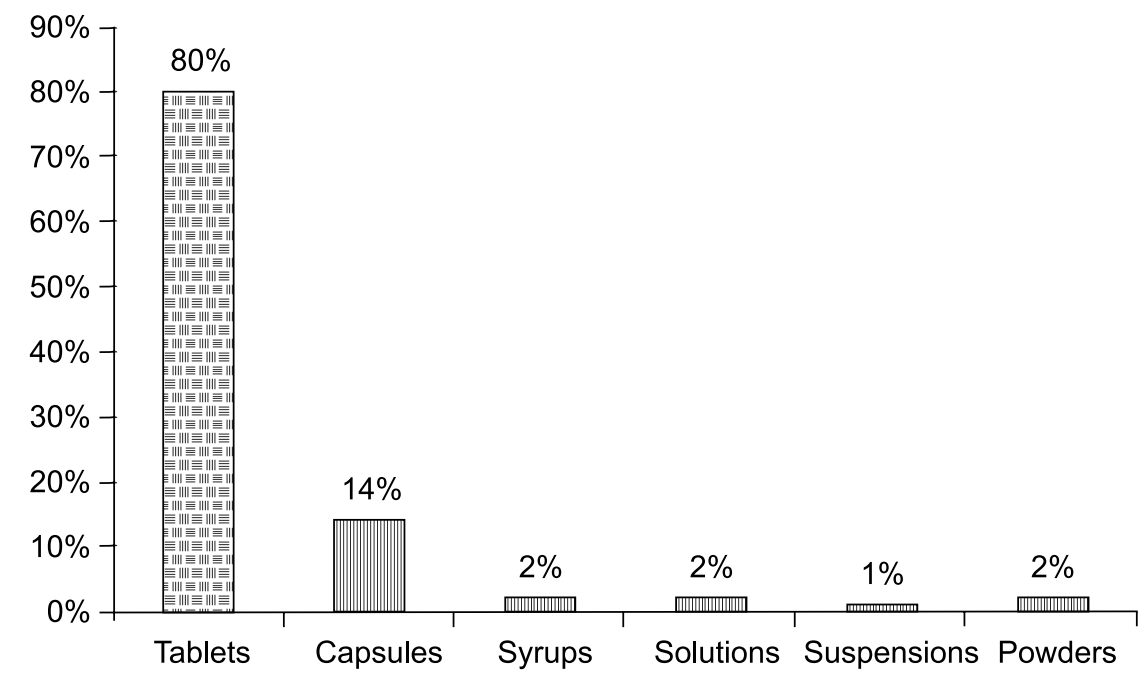

Fig. 2. The range of anti-epileptic drugs at the pharmaceutical market of Ukraine as of September 2013. 
to the time of the pharmacological effect manifestation: suppositories are close to parenteral drugs, but their introduction does not violate the integrity of the skin cover and does not require the involvement of the medical personnel. In addition, rectal application of drugs very often makes it possible to reduce a single dose by their extended release from suppositories. Many drugs after oral introduction are inactivated by enzymes of digestive juices, exhibit undesirable effects on the gastrointestinal tract and liver. Rectal dosage forms are deprived of these drawbacks. Suppositories significantly reduce allergic reactions. With their use there is no problem of taste and odour of drugs, simplicity and painlessness of insertion.

\section{CONCLUSIONS}

In this work attention was paid to the analysis of the Ukrainian pharmaceutical market of drugs for the treatment of epilepsy. It has been found that the market is represented by 164 names. Of them only $1 / 4$ of all drugs are domestic ones and the rest drugs are imported. Among countries-suppliers medicines from India, Germany, Poland, Austria, etc., dominate. A significant share of all drugs accounts for tablets and capsules, then syrups, solutions, suspensions, powders come. Such medicinal form as suppositories is absent at the Ukrainian market in spite of several advantages that are inherent in them.

In view of the above it can be concluded that the solution of the problem of creating new, more effective and less toxic drugs for the treatment of epilepsy is relevant and promising for medical and pharmaceutical science. Increase of the treatment efficiency and safety can only be done with the help of modern drugs. But these drugs are expensive and in most cases are not available to patients. Therefore, development of new competitive (by efficacy, safety and cost) drugs in the form of suppositories for use in medical practice of convulsive diseases treatment is a relevant, timely and prospective task of pharmaceutical science and industry.

\section{REFERENCES}

1. Держсавний реєстр лікарських засобів [Електронний ресурс]. - Режсим достуny: http://www.drlz.kiev.ua/

2. Козлова Н.Г., Романова Я.Ю., Замараева Е.Е., Долгая И.Н. // Фармаком. - 2005. - №2-3. - С. 25-30.

3. Компендіум 2011 - лікарські препарати / Під ред. В.Н.Коваленко, А.П.Вікторова. - К.: МОРІОН, 2011. $2320 \mathrm{c.}$

4. Трунова Т.В., Штриголь С.Ю., Крутських Т.В. та ін. // Укр. біофармаи. журн. - 2012. - №4 (21). C. 25-28.

5. ЦЦимбалюк В.I. // Здоров 'я України. - 2003. - №81. - C. 34-35.

6. Эпилепсия [Электронный ресурс]. Всемирная организация здравоохранения. - Информаиионный бюлл. №999. - 2012. - Режим достуna: http://www.who.int/mediacentre/factsheets/fs999/ru/index.html

7. Anatomical Therapeutic Chemical Classification / WHO Collaborating Centre for Drug Statistics Methodology. Oslo, 2007. - 48 p.

8. Brodie M.J. Anti-epileptic drugs: past, present and future /Ed. M.G.Brodie // Abstract Book $7^{\text {th }}$ Asian \& Oceanian Epilepsy Congress, China. - Hong Kong, 2008. - P. 3.

9. Hovinga C.A. // Exper. Opin. Invest. Drugs. - 2002. - Vol. 11, №10. - P. 1387-1406.

10. Kwan P., Brodie M.J. // Exp. Open. Emerging Drugs. - 2007. - Vol. 12, №3 - P. 407-422.

11. Scott R.A., Lhatoo S.D., Sander J.W. // Bull. World Health Organ. - 2001. - Vol. 79, No4. - P. 344-351.

12. Semah F. // Epileptic Disord. - 2004. - Vol. 6, №4. - P. 255-265.

13. Sirven J.I., Sperling M., Wingerchuk D.M. // Cochrane Database of Systematic Rev. - 2001. - Vol. 3. - P. 58.

14. Weaver D.F. // Can. J. Neurol. Sci. - 2003. - Vol. 30, №1. - P. 4-7.

\section{ДОСЛІДЖЕННЯ АСОРТИМЕНТУ ТА ТОВАРОЗНАВЧИЙ АНАЛІЗ ПРОТИЕПІЛЕПТИЧНИХ ЗАСОБІВ, ПРЕДСТАВЛЕНИХ НА ФАРМАЦЕВТИЧНОМУ РИНКУ УКРАЇНИ Т.В.Трунова \\ Ключові слова: епілепсія; протиепілептичні препарати; лікарська фрорма; супозиторії} Зәідно з даними сучасної статистики епілепсія є одним з найбільш тяжких та розповсюджених захворювань нервової системи. За оцінкою ВООЗ у всьому світі на епілепсію страждають близько 50 мільйонів осіб, зокрема в Україні 500 тис. таких хворих, серед яких близько $65 \%$ становлять особи дитячого та юнацького віку. Проблема адекватного лікування даної патології $є$ однією з найскладніших у клінічній неврології та психіатрії. Було проведено дослідження українського фрармацевтичного ринку протиепілептичних засобів за формою випуску та країною-виробником, визначено потребу в цих засобах на соціальному рівні. Був проведений аналіз споживчих властивостей лікарських препаратів у формі супозиторіїв та їхні перспективи у розвитку лікування епілепсії, що вирішить проблему створення нових більш ефективних та менш токсичних лікарських засобів для терапії даної патології. Основна частка лікарських препаратів даної групи імпортується до України зарубіжними фрармацевтичними компаніями. Ці обставини приводять до того, що з кожним роком збільшуються дослідження 
та стають різноманітнішими методи пошуку нових можливих протиепілептичних препаратів. Узагальнює усі дослідження в цьому напрямку иілеспрямованість пошуку і у випадку створення аналогів існуючих лікарських засобів, і у випадку їх можливих продуктів метаболізму. У зв'язку з вищевикладеним можна зробити висновок, що проблема створення нових більш ефрективних та менш токсичних лікарських засобів для лікування епілепсії є актуальною та перспективною для медичної та фрармацевтичної науки. Підвищити ефективність лікування і зробити його безпечним можна лише за допомогою сучасних лікарських препаратів.

\section{ИССЛЕДОВАНИЯ АССОРТИМЕНТА И ТОВАРОВЕДЧЕСКИЙ АНАЛИЗ ПРОТИВОЭПИЛЕПТИЧЕСКИХ СРЕДСТВ, ПРЕДСТАВЛЕННЫХ НА ФАРМАЦЕВТИЧЕСКОМ РЫНКЕ УКРАИНЫ \\ Т.В.Трунова}

Ключевые слова: эпилепсия; противоэпилептические препараты; лекарственная фрорма; суппозитории

Согласно данных современной статистики эпилепсия является одним из наиболее тяжелых и распространенных заболеваний нервной системы. По оценке ВООЗ во всем мире эпилепсией страдают около 50 миллионов человек, в частности в Украине 500 тыс. таких больных, среди которых около 65\% представляют лица детского и юношеского возраста. Проблема адекватного лечения данной патологии является одной из самых сложных в клинической неврологии и психиатрии. Проведено исследование украинского фрармацевтического рынка противоэпилептических средств по форме выпуска и стране-производителю, определена потребность этих средств на социальном уровне. Был проведен анализ потребительских свойств лекарственных препаратов в форме суппозиториев и их перспективы в развитии лечения эпилепсии, что решит проблему создания новых более эффрективных и менее токсичных лекарственных средств для терапии данной патологии. Основная часть лекарственных препаратов данной группы импортируется в Украину зарубежными фрармацевтическими компаниями. Эти обстоятельства приводят к тому, что с каждым годом расширяются исследования, которые становятся более разносторонними в поиске новых возможных противоэпилептических препаратов. Обобщает все исследования в этом направлении целенаправленность поиска и в случае создания аналогов существующих лекарственных средств, и в случае их возможных продуктов метаболизма. В связи с вышеизложенным можно сделать вывод, что проблема создания новых более эфррективных и менее токсичных лекарственных средств для лечения эпилепсии является актуальной и перспективной для медицинской и фрармацевтической науки. Повысить эффективность лечения и сделать его безопасным можно лишь с помощью современных лекарственных препаратов. 